\title{
ANALISIS KORESPONDENSI SARANA BELAJAR DAN TENAGA PENGAJAR TERHADAP PRESTASI BELAJAR SISWA SMA DAN SMK DI KOTA PALOPO
}

\author{
Oleh, ${ }^{1}$ Nurwahida, ${ }^{2}$ Alia Lestari \\ ${ }^{1,2}$ Pendidikan Matematika IAIN Palopo \\ E-mail: ${ }^{1}$ ida.wahida50@yahoo.com,${ }^{2}$ alia lestari@iainpalopo.ac.id
}

\begin{abstract}
Abstrak
Analisis korespondensi merupakan salah satu teknik multivariat yang merupakan gabungan dari teknik reduksi data dan pemetaan persepsi. Salah satu tujuan analisis ini adalah untuk melihat keterkaitan atau kedekatan suatu kategori pada satu variabel terhadap kategori variabel lainnya. Pada makalah ini akan dibahas penerapan analisis korespondensi dalam melihat pola hubungan antara faktorfaktor eksternal dengan hasil belajar siswa SMA dan SMK di Kota Palopo. Data diperoleh dari dokumentasi Dinas Pendidikan Kota Palopo. Hasil analisis menunjukkan faktor eksternal yang memiliki hubungan yang berarti dengan prestasi belajar adalah tenaga pengajar. Hal ini didukung oleh pola hubungan yang dihasilkan dari plot analisis korespondensi yang menjelaskan bahwa prestasi belajar yang tinggi lebih banyak diperoleh dari sekolah dengan Tenaga Pengajar Baik (TPB) sementara sekolah yang memiliki tenaga pengajar kurang baik (TPKB) dan tenaga pengajar cukup baik (TPCB) cenderung mendapat prestasi sedang dan kurang.
\end{abstract}

Kata Kunci : Analisis Korespondensi, Sarana Belajar, Tenaga Pengajar, Prestasi Belajar.

\section{PENDAHULUAN}

Dalam pembelajaran ada dua faktor yang tidak dapat dipisahkan yaitu faktor internal dan faktor eksternal. Faktor internal adalah faktor yang datangnya dari seseorang yang sedang belajar, seperti kecerdasan, kesiapan, motivasi, minat dan kebiasaan belajar. Sedangkan faktor eksternal datangnya dari lingkungan luar, di antaranya keadaan keluarga, lingkungan sekolah dan lingkungan masyarakat.

Sarana belajar dan tenaga pengajar adalah faktor eksternal yang terdapat pada lingkungan sekolah. Sarana belajar dapat memudahkan siswa menerima materi pembelajaran. Peran para pengajar sebagai guru atau fasilitator perlu ditumbuh kembangkan kemampuannya, yaitu dirangsang motivasi, kreaktivitas inovasinya, profesionalismenya, sehingga menciptakan iklim pembelajaran yang lebih kondusif serta inovasi dalam memberikan materi pelajaran.

Salah satu analisis statistik yang penulis temukan dari beberapa buku statistik yaitu analisis korespondensi. Adapun 
tujuan analisis korespondensi adalah untuk melihat keterkaitan atau kedekatan suatu kategori pada satu variabel terhadap kategori variabel lainnya.[4]

Pada penelitian ini objek yang diamati adalah siswa-siswi SMA dan SMK, sarana belajar, tenaga pengajar dan prestasi belajar. Terdapat penelitian terdahulu yang memiliki beberapa variabel yang sama namun menggunakan analisis yang berbeda yaitu penelitian yang dilakukan oleh Nurhayati, Indah Dwi, dengan judul "Pengaruh Lingkungan dan Sarana Prasarana Belajar terhadap Prestasi Belajar (Studi Pada KKPI Siswa Kelas I APK SMK Muhammadiyah 3 Singosari)".Penelitian ini menggunakan teknik analisis statistik deskriptif dan inferensial, adapun variabel lingkungan dan sarana prasarana belajar dalam penelitian ini merupakan salah satu diantara faktor yang mendukung dalam pencapaian prestasi belajar siswa. Lingkungan dan sarana prasarana belajar yang baik serta mendukung tentu akan meningkatkan prestasi belajar dari siswa agar lebih maksimal. Terdapat dua faktor yang menjadi bagian dari lingkungan yaitu lingkungan keluarga dan lingkungan sekolah. Untuk faktor sarana prasarana belajar juga terdapat dua faktor yaitu sarana prasarana belajar di rumah dan sarana prasarana belajar di sekolah. Faktorfaktor tersebut tentunya sangat diperlukan sebagai upaya pencapaian prestasi yang maksimal dalam belajar.[5]

Oleh karena itu, berdasarkan latar belakang yang telah diuraikan di atas, maka penulis berinisiatif untuk menganalisis lebih lanjut tentang kemungkinan adanya hubungan sarana belajar dan tenaga pengajar terhadap prestasi belajar siswa SMA dan SMK di Kota Palopo dengan menggunakan analisis korespondensi. Sarana belajar yang dimaksud adalah ruang guru, ruang kelas, aula, masjid, dan ruang osis. Sedangkan tenaga pengajar yang dimaksud yaitu jabatan dan status, pendidikan terakhir, usia guru, dan masa kerja guru. Sementara prestasi belajar siswa di lihat dari nilai ratarata siswa tiap sekolah.

\section{METODE PENELITIAN}

Penelitian ini akan dilaksanakan di kota Palopo yang mencakup semua Sekolah Menengah Atas (SMA) dan Sekolah Menengah Kejuruan (SMK) yang ada di Kota Palopo baik negeri maupun swasta tahun ajaran 2015 dan teknik pengumpulan data yang digunakan yaitu dokumentasi.

Metode penelitian yang digunakan adalah penelitian kuantitatif deksriptif yaitu menjelaskan hubungan antar variabel 
65 | al-Khwarizmi, Volume III, Edisi 2, Oktober 2015, Hal. 63 - 70

dengan menganalisis data numerik (angka) menggunakan metode statistik melalui pengujian hipotesa.[2]

Adapun langkah-langkah analisis data dalam penelitian ini yaitu:

\section{Melakukan transformasi data}

Transformasi data berupa perubahan dari bentuk awal data ke dalam bentuk rasio. Sarana belajar berupa rasio ruang guru, rasio ruang kelas, rasio ruang UKS, rasio ruang aula dan rasio mushola atau masjid.

$$
\text { Rasio Sarana Belajar }=\frac{\text { jumlah orang }}{\text { jumlah ruang }}
$$

Tenaga pengajar dapat dilihat dari rasio jabatan dan status, rasio pendidikan terakhir, rasio usia guru, dan rasio masa kerja guru. Rasio status kepegawaian adalah angka perbandingan banyaknya tenaga pengajar golongan tertentu dengan banyaknya sekolah per kecamatan. Rasio pendidikan terakhir adalah angka perbandingan banyaknya tenaga pengajar berpengajaran tertentu dengan banyaknya sekolah per kecamatan. Rasio lama pengabdian adalah angka perbandingan banyaknya tenaga pengajar dengan masa tertentu dengan banyaknya sekolah per kecamatan.[1]

\section{Melakukan analisis klaster}

Analisis klaster dalam penelitian ini digunakan untuk menyesuaikan data yang berbentuk per wilayah kecamatan agar dapat digunakan dalam analisis korespondensi. Langkah pengelompokan dalam analisis cluster mencakup 3 hal berikut : (a) Mengukur kesamaan jarak, (b) Membentuk cluster secara hirarkis, (c) Menentukan jumlah cluster.[3]

\section{Menentukan tabel kontingensi}

Tabel kontingensi dua arah adalah tabel yang mencatat data hasil pengamatan dengan melibatkan dua variabel, variabel I dan variabel II. Variabel I sebagai variabel baris terdiri dari $i$ kategori, dan variabel II sebagai variabel kolom terdiri dari $j$ kategori. Dalam tabel kontingensi terdapat sebuah frekuensi harapan yang berkorespondensi dengan masing-masing frekuensi pengamatan, dimana frekuensi harapan ini dihitung berdasarkan hipotesis sesuai dengan aturan - aturan probabilitas. Frekuensi -frekuensi ini, yang menempati sel-sel pada sebuah tabel kontingensi, disebut frekuensi-frekuensi sel. Adapun frekuensi total pada masingmasing baris atau kolom disebut sebagai frekuensi marjinal.[6]

\section{Melakukan Uji Chi-square}

Cara menguji $\chi^{2}$ pertama buatlah hipotesis berbentuk kalimat, tetapkan tingkat signifikansi, hitunglah nilai $\chi^{2}$, buatlah kaidah 
keputusan yaitu jika $\chi^{2}$ hitung $\geq \chi^{2}$ tabel, maka tolak $H_{0}$ artinya signifikan, carilah $\chi^{2}$ tabel dengan menggunakan tabel $\chi^{2}$ kemudian buatlah perbandingan antara $\chi^{2}$ hitung dengan $\chi^{2}$ tabel, yang terakhir simpulkan. Rumus yang digunakan untuk menghitung $\chi^{2}$ yaitu: [5]

$$
\chi^{2}=\sum \frac{\left(f_{0}-f_{e}\right)^{2}}{f_{e}}
$$

5. Melakukan analisis korespondensi

Analisis korespondensi merupakan bagian analisis multivariat yang mempelajari hubungan antara dua atau lebih variabel dengan memperagakan baris dan kolom secara serempak dari tabel kontingensi dua arah dalam ruang vektor berdimensi rendah. Tahap-tahap dalam analisis korespondensi adalah sebagai berikut: (1) Dari tabel kontingensi data asal di susun ke dalam bentuk matriks dan dilakukan penguraian nilai singular untuk mengetahui nilai variabilitas data asli yang dijelaskan oleh setiap dimensi yang dihasilkan dan (2) Melakukan analisis korespondensi pada masingmasing tabel kontingensi dengan bantuan software SPSS.[4]

\section{HASIL DAN PEMBAHASAN}

Setelah dilakukan pengumpulan data maka selanjutnya penulis akan mengelompokkan data berdasarkan nilai awal yang diperoleh ke dalam tiga variabel indikator prestasi, yang selanjutnya akan digunakan untuk menjelaskan hasil analisis korespondensi yaitu diantaranya adalah:

1) Berprestasi $X$ dengan nilai $70-79$

2) Berprestasi $Y$ dengan nilai $60-69$

3) Berprestasi $Z$ dengan nilai 50 - 59

Pengelompokkan di atas diambil dari nilai rata-rata yang tertinggi untuk prestasi $\mathrm{X}$ dan nilai yang terendah untuk prestasi $\mathrm{Z}$.

1. Hasil analisis sarana belajar terhadap prestasi belajar

Data awal yang terdiri dari sarana belajar, akan diubah ke dalam data rasio, karena setiap kecamatan tidak memiliki jumlah sekolah yang sama, seperti pada lampiran 1, kemudian dilanjutkan dengan menganalisis data rasio sarana belajar menggunakan analisis klaster seperti pada tabel 1 .

Pada tabel 1, apabila dibentuk 4 klaster untuk sarana belajar maka diperoleh: anggota klaster 1 yaitu Wara, anggota klaster 2 yaitu Wara Utara, anggota klaster 3 yaitu Wara Selatan, Wara Barat, Telluwa-nua, Sendana dan Mungkajang dan anggota klaster 4 yaitu Bara 
67 | al-Khwarizmi, Volume III, Edisi 2, Oktober 2015, Hal. 63 - 70

Tabel 1. Cluster Membership

\begin{tabular}{|l|l|l|}
\hline \multicolumn{1}{|c|}{ Case } & 4 Clusters & 3 Clusters \\
\hline 1:Wara & 1 & 1 \\
2:Wara Utara & 2 & 2 \\
3:Wara Selatan & 3 & 3 \\
4:Wara Barat & 3 & 3 \\
5:Bara & 4 & 2 \\
6:Telluwa-nua & 3 & 3 \\
7:Sendana & 3 & 3 \\
8:Mungkajang & 3 & 3 \\
\hline
\end{tabular}

Pada tabel 2, nampak bahwa sarana belajar cukup lengkap memiliki prestasi X (tinggi) sebanyak 1 kecamatan, tidap terdapat kecamatan yang memiliki sarana belajar kurang lengkap dengan prestasi $\mathrm{Y}$ (sedang), sarana belajar lengkap memiliki prestasi $\mathrm{X}$ (tinggi) sebanyak 1 kecamatan dan sarana belajar tidak lengkap memiliki 2 kecamatan dengan prestasi Z (kurang). Dengan menggunakan SPSS diperoleh tabel 3.

Tabel 2. Prestasi * Sarana Belajar Crosstabulation

\begin{tabular}{|cc|c|c|c|c|c|}
\hline & & \multicolumn{4}{|c|}{ Sarana Belajar } & \multirow{2}{*}{ Total } \\
\cline { 2 - 6 } & & SBCL & SBKL & SBL & SBTL & \\
\hline \multirow{3}{*}{ Prestasi } & X & 1 & 1 & 1 & 0 & 3 \\
& Y & 0 & 0 & 0 & 3 & 3 \\
& Z & 0 & 0 & 0 & 2 & 2 \\
\multicolumn{2}{|c|}{ Total } & 1 & 1 & 1 & 5 & 8 \\
\hline
\end{tabular}

Tabel 3. Chi-Square Tests Sarana Belajar

\begin{tabular}{|l|r|r|r|}
\hline & \multicolumn{1}{|c|}{ Value } & \multicolumn{1}{c|}{ Df } & Asymp. Sig. (2-sided) \\
\hline Pearson Chi-Square & $8,000^{\mathrm{a}}$ & 6 &, 238 \\
Likelihood Ratio & 10,585 & 6 &, 102 \\
N of Valid Cases & 8 & & \\
\hline
\end{tabular}

a. 12 cells $(100,0 \%)$ have expected count less than 5 . The minimum expected count is, 25 .

Pada tabel 3, diketahui nilai $\chi^{2}=8,000$, untuk derajat bebas (df) $=6$ dan Asym.Sig (2-sided) $=0,238$. Jika tingkat signifikansi $\alpha=$ 0,05 dan $0.05<0,238$ maka $\mathrm{H}_{0}$ diterima dapat dikatakan bahwa sarana belajar tidak memiliki hubungan yang signifikan terhadap prestasi belajar. 


\section{Hasil plot analisis korespondensi}

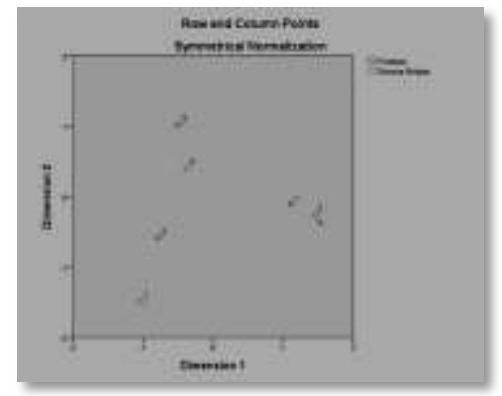

Dari hasil analisis korespondensi di atas, nampak bahwa sarana belajar kurang lengkap (SBKL) dan sarana belajar tidak lengkap (SBTL) cenderung dekat dengan prestasi tinggi (X), sarana belajar lengkap dekat dengan prestasi $\mathrm{Z}$ dan sarana belajar cukup lengkap (SBCL) dekat dengan prestasi Y. Hal ini menunjukkan bahwa sarana belajar tidak terlalu berperan dalam menciptakan prestasi belajar.

2. Hasil analisis tenaga pengajar terhadap prestasi belajar

Data awal yang terdiri dari tenaga pengajar, akan diubah ke dalam data rasio, karena setiap kecamatan tidak memiliki jumlah sekolah yang sama, seperti pada lampiran 2 dan lampiran 3, kemudian dilanjutkan dengan menganalisis data rasio tenaga pengajar menggunakan analisis klaster seperti pada tabel 4. Pada tabel 4, apabila dibentuk 3 klaster untuk tenaga pengajar maka diperoleh: anggota klaster 1 ada lima yaitu Wara, Wara Utara, Wara Selatan, Wara Barat, Bara, anggota klaster 2 ada satu yaitu Tellu-wanua, anggota klaster 3 ada dua yaitu Sendana dan Mungkajang.

\section{Tabel 4. Cluster Membership}

\begin{tabular}{|l|l|l|}
\hline Case & 3 Clusters & 2 Clusters \\
\hline 1:Wara & 1 & 1 \\
2:Wara Utara & 1 & 1 \\
3:Wara Selatan & 1 & 1 \\
4:Wara Barat & 1 & 1 \\
5:Bara & 1 & 1 \\
6:Telluwa-nua & 2 & 1 \\
7:Sendana & 3 & 2 \\
8:Mungkajang & 3 & 2 \\
\hline
\end{tabular}

Dari tabel 5, nampak bahwa tenaga pengajar baik yang memiliki prestasi $X$ (tinggi) sebanyak 3 kecamatan, tenaga pengajar cukup baik yang berprestasi $\mathrm{Y}$ (sedang) sebanyak 1 kecamatan dan tenaga pengajar kurang baik yang memiliki prestasi 
69 | al-Khwarizmi, Volume III, Edisi 2, Oktober 2015, Hal. 63 - 70

$\mathrm{Z}$ (kurang) sebanyak 2 kecamatan. Dengan menggunakan SPSS diperoleh tabel 6.

Tabel 5. Prestasi * Tenaga Pengajar Crosstabulation

\begin{tabular}{|c|c|c|c|c|c|}
\hline & \multicolumn{3}{|c|}{ Tenaga Pengajar } & \multirow[b]{2}{*}{ Total } \\
\hline & & TPB & TPCB & TPKB & \\
\hline & $\mathrm{X}$ & 3 & 0 & 0 & 3 \\
\hline & $\mathrm{Y}$ & 2 & 1 & 0 & 3 \\
\hline Prestasi & $\mathrm{Z}$ & 0 & 0 & 2 & 2 \\
\hline Total & & 5 & 1 & 2 & 8 \\
\hline
\end{tabular}

Tabel 6. Chi-Square Tests

\begin{tabular}{|l|r|r|r|}
\hline & \multicolumn{1}{|c|}{ Value } & df & Asymp. Sig. (2-sided) \\
\hline Pearson Chi-Square & $9,600^{a}$ & 4 &, 048 \\
Likelihood Ratio & 10,585 & 4 &, 032 \\
Linear-by-Linear Association & 5,228 & 1 &, 022 \\
N of Valid Cases & 8 & & \\
\hline
\end{tabular}

a. 9 cells $(100,0 \%)$ have expected count less than 5 . The minimum expected count is, 25 .

Pada tabel Chi-Square test tenaga pengajar diketahui nilai $\chi^{2}$ $=9,600$ dengan derajat bebas $(\mathrm{df})=4$ dan Asym.Sig (2sided) $=0,048$. Jika tingkat signifikansi $\alpha=0,05$ dan $0.05>0,048$ maka $\mathrm{H}_{0}$ ditolak maka dapat disimpulkan ada hubungan antara prestasi dengan tenaga pengajar. Sehingga untuk mengetahui pola hubungan variabel dapat dilanjutkan menggunakan analisis korespondensi.

Hasil analisis korespondensi di bawah, variabel tenaga pengajar baik (TPB) memiliki kedekatan dengan prestasi X, tenaga pengajar cukup baik (TPCB) memiliki kedekatan dengan prestasi $\mathrm{Y}$ sementara tenaga pengajar kurang baik (TPKB) sangat berdekatan dengan prestasi $\mathrm{Z}$. Terlihat pula prestasi X cenderung menjauhi tenaga pengajar cukup baik dan tenaga pengajar kurang baik. Hal ini membuktikan bahwa tenaga pengajar memiliki pengaruh yang besar dalam meningkatkan prestasi belajar siswa.

\section{Hasil plot analisis korespondensi.}






\section{KESIMPULAN}

Berdasarkan hasil analisis untuk mengetahui hubungan antara prestasi belajar dengan sarana belajar dan tenaga pengajar dengan menggunakan analisis korespondensi maka didapat kesimpulan sebagai berikut:

1. Terdapat hubungan prestasi belajar dengan tenaga pengajar

2. Prestasi $X$ cenderung diperoleh dari sekolah dengan sarana belajar kurang lengkap (SBKL) dan sarana belajar tidak lengkap (SBTL), prestasi Z cenderung diperoleh dari sekolah dengan sarana belajar lengkap (SBL) serta sarana belajar cukup lengkap (SBCL) cenderung dekat dengan prestasi $\mathrm{Y}$, dan untuk variabel tenaga pengajar prestasi $\mathrm{X}$ lebih banyak diperoleh dari sekolah dengan tenaga pengajar baik (TPB) sementara sekolah yang memiliki tenaga pengajar kurang baik (TPKB) dan tenaga pengajar cukup baik (TPCB) cenderung mendapat prestasi $\mathrm{Y}$ dan $\mathrm{Z}$.

\section{DAFTAR PUSTAKA}

Anggraini, Analisis Korespondensi, http:// repository.uinjkt. ac.id/dspace /bitstream/123456789/4825/1/ANGGRAINIFST.pdf., (diakses tanggal 16 Agustus 2015)

Arikunto Suharsimi, Prosedur Penelitian Suatu Pendekatan Praktek, (Cet.XII; Jakarta: Rineka Cipta, 1992).

Bambang Ruswandi, Diktat Perkuliahan Praktikum Statistika Multivariat, (Jakarta: FST UIN, 2008).

Joseph F.Hair, et.al., Multivariate Data Analysis, (New Jersey:Prentice Hall, 2006).

Nurhayati, Indah Dwi, Pengaruh Lingkungan dan Sarana Prasarana Belajar terhadap Prestasi Belajar (Studi Pada KKPI Siswa Kelas I APK SMK Muhammadiyah 3 Singosari), $\quad$ http://karyailmiah.um.ac.id/index.php/manajemen/article/view/3984, Skripsi, 2007 ( diakses tanggal 30 Agustus 2015).

Spiegel Murray R., Schaum Outlines Statistik, (Jakarta: Penerbit Erlangga, 2002). 